IZA DP No. 9640

Remittances and Expenditure Patterns of the Left Behinds in Rural China

Sylvie Démurger

Xiaoqian Wang

January 2016 


\title{
Remittances and Expenditure Patterns of the Left Behinds in Rural China
}

\author{
Sylvie Démurger \\ Université de Lyon, CNRS, GATE \\ and IZA \\ Xiaoqian Wang \\ CNRS and GATE \\ Discussion Paper No. 9640 \\ January 2016 \\ IZA \\ P.O. Box 7240 \\ 53072 Bonn \\ Germany \\ Phone: +49-228-3894-0 \\ Fax: +49-228-3894-180 \\ E-mail: iza@iza.org
}

Any opinions expressed here are those of the author(s) and not those of IZA. Research published in this series may include views on policy, but the institute itself takes no institutional policy positions. The IZA research network is committed to the IZA Guiding Principles of Research Integrity.

The Institute for the Study of Labor (IZA) in Bonn is a local and virtual international research center and a place of communication between science, politics and business. IZA is an independent nonprofit organization supported by Deutsche Post Foundation. The center is associated with the University of Bonn and offers a stimulating research environment through its international network, workshops and conferences, data service, project support, research visits and doctoral program. IZA engages in (i) original and internationally competitive research in all fields of labor economics, (ii) development of policy concepts, and (iii) dissemination of research results and concepts to the interested public.

IZA Discussion Papers often represent preliminary work and are circulated to encourage discussion. Citation of such a paper should account for its provisional character. A revised version may be available directly from the author. 


\section{ABSTRACT}

\section{Remittances and Expenditure Patterns of the Left Behinds in Rural China*}

This paper investigates how private transfers from internal migration in China affect the expenditure behaviour of families left behind in rural areas. Using data from the Rural-Urban Migration in China (RUMiC) survey, we assess the impact of remittances sent to rural households on consumption-type and investment-type expenditures. We apply propensity score matching to account for the selection of households into receiving remittances, and estimate average treatment effects on the treated. We find that remittances supplement income in rural China and lead to increased consumption rather than increased investment. Moreover, we find evidence of a strong negative impact on education expenditures, which could be detrimental to sustaining investment in human capital in poor rural areas in China.

JEL Classification: $\quad$ O15, J22, R23, D13, O53

Keywords: remittances, labour migration, expenditure behaviour, left-behind, China, propensity score matching

Corresponding author:

Sylvie Démurger

GATE Lyon Saint-Etienne

93 Chemin des Mouilles

69130 Ecully

France

E-mail: demurger@gate.cnrs.fr

\footnotetext{
* We are grateful to the editors, Massimiliano Tani and Klaus F. Zimmermann, and to three anonymous reviewers for their careful reading of our paper and their constructive comments. We also thank Sinem $\mathrm{H}$. Ayhan, Samia Badji and participants at the $10^{\text {th }}$ IZA/World Bank Conference on Employment and Development and at the $7^{\text {th }}$ IZA/CIER Annual Workshop on Research in Labor Economics. This research is part of the Agence Nationale de la Recherche (ANR) research program ANR-14-ORAR0002-01, whose financial support is gratefully acknowledged.
} 


\section{Introduction}

More than one billion people worldwide are estimated to be living and working outside of their origin communities, be they international or internal migrants. In the developing world, remittances sent by migrants make a direct contribution to increasing income of the families left behind, and as such they contribute to easing budget constraints of the poorest, reducing poverty and improving average living conditions (Acosta et al., 2008). How these private transfers are spent or used by the families left behind is yet another issue, with potentially important consequences for the economic development in migrantsending communities. In theory, remittances may alter household expenditure patterns in various ways, depending on how these financial flows are considered by the left behinds (Adams and Cuecuecha, 2010, 2013). If migrants are treated as full family members and their income as part of the pooled household income, then remittances are expected to be used as any other source of income and one should not observe any behavioural change in expenditure (Castaldo and Reilly, 2007; Adams et al., 2008). Another strand of the literature focuses on the role that remittances play on relaxing the budget constraint of the family left behind. A pessimistic view argues that remittances may leave investment decisions unchanged if they are spent on status-oriented, conspicuous consumption, and as such they may have little impact on local economies. A more optimistic view argues that remittances are a transitory source of income for families left behind, and are therefore invested, at the margin, rather than consumed. In that case, remittances may foster investment in human and physical capital at home (Adams, 1998).

The purpose of this paper is to examine how remittances sent by rural-to-urban migrants are spent by families left behind in rural China, by using a large cross-sectional dataset, the Rural-Urban Migration in China (RUMiC) database for the year 2007. China provides an interesting ground to explore the impact of remittances on sending communities because the country is currently experiencing the greatest internal labour migration in history. On April 29, 2015, the National Bureau of Statistics of China released the 2014 Rural-urban Migration Monitoring Survey showing that the total number of internal migrant workers amount to 274 million, which is more than the total stock of international migrants worldwide. Although there is no official survey on total remittances sent by internal migrants in China, Cheng and $\mathrm{Xu}$ (2005) estimated that in 2005 the total remittances sent by rural migrants to their family left behind was ranging between 191 and 330 billion yuan. $\mathrm{Hu}$ and Shi (2013) corroborate these findings and estimate that China's annual remittances from rural migrants amount to more than 300 billion yuan. 
Empirical studies on remittances and household expenditure behaviour in migrantsending regions provide mixed evidence. A broad literature has highlighted the positive effect of remittances on the investment activities of the left behinds. For example, using the 2005-06 Ghana Living Standards Survey, Adams and Cuecuecha (2013) find that remittances are spent more at the margin on investment goods including education, housing, and health than on food. Similar conclusions have been reached on Guatemala (Adams and Cuecuecha, 2010), Ecuador (Göbel, 2013), Colombia (Cardona-Sosa and Medina, 2006), Mexico (Taylor and Mora, 2006; Amuedo-Dorantes and Pozo, 2011), the Philippines (Yang, 2008), Nigeria (Osili, 2004) or Eritrea (Kifle, 2007). Yet, a few recent studies show that in some countries, remittances are not put to productive uses and tend to leave investment expenditure behaviour unchanged. Using the 2003 Tajikistan Living Standards Measurement Survey, Clément (2011) finds no evidence of any positive impact of remittances on investment expenditures. Instead, remittances are regarded as short-term coping strategies helping left behind households achieving a basic level of consumption. Cattaneo (2012) finds no education enhancing effect of remittances sent to Albania by international migrants and ascribes the low share of investment expenditures to the weakness of local education systems.

As far as China is concerned, empirical findings from the still scarce literature on remittances and expenditure patterns of the left behinds also contrast with the optimistic view of remittances as a mean to increased investment in sending communities. Using data collected from 60 randomly selected villages of 6 provinces in rural China, de Brauw and Rozelle (2008) find a significant relationship between migration and consumptive investment (measured by investment in housing and durable goods) between 1995 and 2000, but no significant relationship between migration and productive investment. The relationship between migration and consumptive investment is shown to be particularly strong in non-poor areas, whereas it is not significant in poor areas. Exploiting data collected in 2006 on 1,498 households in Anhui and Jiangsu, Zhu et al. (2012) obtain similar findings, with remittances being mainly used for consumption and not for investment purposes. Zhu et al. (2014) confirm that remittances are considered as a permanent source of income by households left behind using data from the Rural Household Survey undertaken by the National Bureau of Statistics (NBS) of China in the provinces of Jiangsu, Anhui and Sichuan in 2001 and 2004.

The contribution of this paper is threefold. First, we investigate how remittances affect the expenditure patterns of receiving households in rural China by using recent data specifically collected to study rural-to-urban migration in China. Unlike small- 
scale databases used in previous studies, the Rural-Urban Migration in China (RUMiC) database is unique by its spatial coverage and its large scale (Akgüc et al., 2014). The rural household survey comprises 8,000 households in 9 provinces and gathers detailed information on household expenditure and its composition. We focus on the differentiated impact of remittances on various expenditure components, which allows us to refine and extend the debate concerning whether remittances do serve any investment purpose in rural China. This is important from a policy point of view because a non-investment use of remittances flowing from the massive labor movement out of rural areas could impede rather than help rural development in the long run.

Second, identifying whether or not remittances influence budget allocation of families receiving these income transfers raises an endogeneity issue: there might be confounding factors that influence both the likelihood of receiving remittances and the household's expenditure behaviour. The existing literature typically uses two main approaches to solve this methodological issue: an instrumental variable (IV) strategy or a propensity score matching (PSM) approach. Unlike previous studies on China that identify the effect of remittances using an IV strategy (de Brauw and Rozelle, 2008; Zhu et al., 2012, 2014), we apply propensity score matching to identify the impact of remittances on the expenditure patterns of the families left behind. In the absence of reliable instruments, the PSM method offers the advantage of controlling for self-selection based on observable characteristics without imposing too strong distributional assumptions (Jimenez-Soto and Brown, 2012), although it relies on a strong identifying assumption of selection on observables.

Third, our findings add to the empirical literature on the impact of migration and remittances on families left behind (Antman, 2013). We find evidence of remittances supplementing income and increasing per capita consumption of rural households, with the effect being stronger for non-poor households. This results are consistent with earlier findings on China on the non-investment use of remittances (de Brauw and Rozelle, 2008). When it comes to budget components, we find that remittance-recipient households allocate a smaller share of their budget to education than non-recipients do, and we thus add evidence to the possible negative effect of migration on education outcomes of children who stay behind. There is a growing strand of the literature on migration and the left behinds that focuses on this specific link and that reaches contrasted conclusions depending on the country studied, the type of migration and the characteristics of those left behind. On the one hand, evidence of a positive effect of remittances on the school attendance of children left behind has been provided in the Philippines (Yang, 2008) and in Mexico (Alcaraz et al., 2012), notably for girls (Antman, 2012). Recently, Böhme (2015) has 
shown that international Moldovan migrants increase education aspirations at home, and Démurger and $\mathrm{Xu}$ (2015) have stressed the importance of education for migrant parents in China. On the other hand, the absence of parents in the household due to migration has been found to lead to reduced investment in children's education in a number of studies. McKenzie and Rapoport (2011) provide evidence that living in a migrant household lowers the probability for boys completing junior high school and for boys and girls completing high school in rural Mexico. Similar findings are highlighted on Albania by Giannelli and Mangiavacchi (2010). In rural China, de Brauw and Giles (2008) show that rural-urban migration opportunities reduce the probability of high school enrolment, and Zhang et al. (2014) find significant negative impacts of being left-behind by both parents on children's cognitive development. The strong evidence of a negative impact of remittances on the education budget share we find in this paper resonates with this literature and points to the ambiguous perception of skill premium in China, notably in the migrant labor market.

The paper proceeds as follows. Section 2 describes the data from rural China and provides descriptive statistics. The empirical strategy is presented in Section 3. Estimation results follow in Section 4. Section 5 concludes.

\section{Data}

The data used in this paper come from the Rural Household Survey administered by the National Bureau of Statistics of China (NBS) under the Rural-Urban Migration in China (RUMiC) project carried out in $2008^{1}$. The survey design and implementation are detailed in Meng et al. (2010) and in Akgüc et al. (2014). The survey covers 8,000 rural households from 800 villages, in 82 counties and nine provinces (Hebei, Jiangsu, Zhejiang, Anhui, Henan, Hubei, Guangdong, Chongqing and Sichuan). It includes detailed information on a wide range of household and individual socio-economic characteristics. At the household level, it provides information on expenditures, assets and remittance income received for the year 2007. A village survey is also attached to the household survey. Missing observations for a few variables, either at the individual or the village level, and outlying data on expenditure reduce our final sample size to 7,682 households.

\footnotetext{
${ }^{1}$ The RUMiC survey consists of three parts: the Urban Household Survey, the Rural Household Survey and the Migrant Household Survey. It was initiated by a group of researchers at the Australian National University, the University of Queensland and Beijing Normal University and was supported by the Institute for the Study of Labor (IZA), which provides the Scientific Use Files. The financial support for RUMiC was obtained from the Australian Research Council, the Australian Agency for International Development (AusAID), the Ford Foundation, IZA and the Chinese Foundation of Social Sciences.
} 
The definition of rural households in the context of migration is worth explaining. Rural households are composed of all members declared during the survey, be they currently living in the village or in another place. Following the NBS definition, migrant-sending households are households with members working outside their home county and having been living away for at least 6 months over the preceding year. Remittance-receiving households consist of all the households who report migration income. They may or may not be migrant-sending households, and this will depend on whether the migrant sends back remittances and on whether the family receives remittances from migrants who are not direct family members (e.g. relatives or friends). As we are interested in the expenditure and the consumption patterns of the left behinds, we impose that per capita variables (income, expenditure and consumption) are defined on household members currently living in the village ${ }^{2}$. The household size is thus calculated excluding household members who were declared as migrants in 2007.

In order to explore the budget allocation patterns of rural households, we consider different types of expenditure that follow the definition provided by the NBS. Total household expenditures are classified in 3 categories: expenditures for household business, consumption expenditures, and other expenditures (including taxes and fees, expenses on properties and on transfers). Expenditures for household business include all expenses related to family agricultural and non-agricultural activities, such as investment in productive fixed assets, employment for the construction of productive fixed assets, etc. Consumption expenditures are further categorized into 5 components: 1) food, clothing and other goods and services; 2) durables goods (including home appliances, furniture, transportation equipment); 3) housing; 4) education, culture and recreational services; 5) health care and medical services ${ }^{3}$. The first category covers pure consumption spending on non-durable goods. Expenditures on durable goods and on housing fall into "consumptive investment" as defined by de Brauw and Rozelle (2008): "consumptive investments directly improve the quality of life for members of the household, by increasing the flow of services from their durable asset stock, rather than helping them raise their income through increased production" (page 323). The last 2 categories correspond to spending on human capital.

\footnotetext{
${ }^{2}$ Excluding current migrants in the calculation of per capita variables implicitly assumes that migrants do not draw anything from the household budget. We cannot rule out the possibility that part of the households' spending may be done by migrants, either at destination if the household is contributing to the living expenses of the migrant, or at home in case of return. By imposing that migrants have been living away for at least 6 months, we limit the importance of very short migration episodes. Yet, we may still over-estimate per capita expenditures of the left behinds.

${ }^{3}$ See Mao and $\mathrm{Xu}$ (2014) for a description of the content of each category.
} 
Unsurprisingly, migrant-sending households and remittance-receiving households do not perfectly match: 3,724 households ( $48.5 \%$ of the sampled households) receive remittances; 3,346 households (43.6\%) are migrant-sending; $19.5 \%$ of the migrant-sending households do not receive remittances, and $23.7 \%$ of the remittance-receiving households are not migrant-sending ${ }^{4}$. Table 1 shows that remittance-receiving households and non remittance-receiving households strongly differ in terms of household characteristics. Households that receive remittances tend to be larger (before migration), they have more adult members but fewer old dependent people, and they are more likely to have children (both pre-school and of school age). Unsurprisingly, remittance-receiving households are disproportionately found in central and western provinces, which are the main rural migrants sending areas in China. In contrast, more than half of non-receiving households live in coastal (migration destination) areas.

Table 2 provides a comparison of the two groups in terms of income and expenditure. Whereas there is no significant difference in total income between non remittance-receiving and remittance-receiving households, there are significant differences in per capita terms. The computation of per capita income either including or excluding migrants reveals interesting features. The migrant-included calculation, which broadly reflects the per capita earnings capacity of the household, shows that non-receiving households are able to earn a significantly higher per capita income than receiving households. The migrant-excluded calculation, which rather reflects the per capita spending capacity of the rural household, shows the exact opposite, with a significantly higher spending capacity of receiving households. This feature is corroborated by the significant gap in per capita consumption level, with remittances-receiving households spending on average $14 \%$ more per capita than non-receiving households. The composition of household income further shows that remittances are a major component of income for receiving households (44\% of their total net income on average) whereas local non-farm sources of income are disproportionally low compared to non-receiving households: the net wage income from local off-farm activities is 3.4 times larger on average for non-receiving households, and the net income from family off-farm operation is 4.1 times larger. These figures all point to the possible strong dependence of receiving families upon the particular source of income made by remittances: they have a lower per capita earnings capacity and are less likely to get income from local off-farm activities, either through wage work or through individual business.

To further document the relation between income and remittances, Table 3 displays

\footnotetext{
${ }^{4}$ This does not necessarily imply that $24 \%$ of the remittance-receiving households have never sent any migrant to cities, but rather that in the year 2007, they had no migrant members (although they received transfers counted as remittances that year).
} 
the distribution of households and the average amount of remittances across pre-migration transfer (i.e. excluding remittances) income quartiles. It shows that households in the first and the second quartile are the most likely to receive remittances: 36.31 percent (resp. 29.40 percent) of households in the bottom (resp. second) quartile of the pre-transfer income distribution receive remittances in 2007. By contrast, the proportion of households receiving remittances in the third and the top quartile is much smaller, at respectively 23.07 percent and 11.22 percent. Interestingly, not only the poorest households are the most likely to receive remittances, but the average amount of remittances they receive is also much larger than that of the other quartiles and it represents a much larger share of their average total income (almost 60 percent as opposed to less than 6 percent for the top quartile). These figures suggest that families that have access to local higherreturns economic activities have less incentive to send migrants (Démurger and Li, 2013), a conjecture also supported by the larger amount of local off-farm income and property income of non remittance-receiving households (Table 2).

Finally, Table 4 documents the relationship between remittances and the expenditure and consumption profile of rural households. Rural households in China allocate almost three quarters of their total spending for consumption, and one-fifth for family business. Remittance-receiving households are found to spend a significantly higher share on both consumption and family business than non-receiving households. The decomposition of consumption expenses into 5 components highlights further differences between households. Unsurprisingly, the main component of households' budget is non-durable goods (mostly food and clothing), which accounts for more than $61 \%$ of the total budget. Cross-tabulations with remittance-receiving status show that the rate is slightly higher for remittance-receiving households, and the difference is statistically significant at 1 percent. Yet, the most obvious difference between remittance-receiving and nonreceiving households appears in the budget share for education, with a gap of more than $20 \%$ in favour of non-receiving households. Whereas non-receiving households spend on average 8.12 percent of their consumption expenses on education, households that receive remittances spend 6.68 percent, and the gap is significant at 1 percent. Given that remittance-receiving households are more likely to have school-aged children (see Table 1), this finding is unexpected and questions expenditure choices made by rural households. The situation is similar for health expenditures although the gap is smaller (6.02 percent against 5.83 percent) and non-significant. In contrast, remittance-receiving households spend relatively more on durable goods than non-receiving households, but not differently on housing. These raw statistics offer first evidence on the use of remittances by the families left behind: remittances represent a large share of income for the poorest 
households and they seem to be spent on consumption more than on investment (notably in human capital).

\section{Methodology}

As in all migration-related studies, exploring the impact of remittances on expenditure patterns of the families left behind requires to address the potential endogeneity of the remittances variable: there may be characteristics that make receiving households systematically different from non-receiving households, and this could lead to biased estimates of the impact of remittances on the outcome of interest. In particular, the likelihood to receive remittances may be affected by the same factors that could also explain household expenditure behaviour. The empirical literature that estimates the impact of remittances on receiving households using cross-sectional data typically resorts to two main techniques to handle this selection issue: an instrumental variable (IV) approach (e.g. Adams and Cuecuecha, 2010, 2013; Göbel, 2013) or a propensity score matching (PSM) approach (e.g. Clément, 2011; Jimenez-Soto and Brown, 2012; Bertoli and Marchetta, 2014). Whereas IV has been shown to work well as an identification strategy, finding a suitable instrument remains a challenge (McKenzie et al., 2010). In the absence of a good candidate for a reliable instrument, we rely on the second approach and apply propensity score matching (Rosenbaum and Rubin, 1983). As discussed below, this method is not without its own faults as it relies on a strong identifying assumption, and various sensitivity tests are needed to assess the quality of the estimates (Caliendo and Kopeinig, 2008).

\subsection{The Propensity Score Matching framework}

Building upon the evaluation literature, the objective of matching methods is to provide a comparison group to a "treated" group in the case of observational studies. In our case, we compare households that receive remittances (the treated group) with otherwise similar households that do not receive remittances (the control group). After correcting for the non-random selection of the treatment participants through matching, we can then estimate average treatment effects on the treated (ATT) that is, the impact that receiving remittances has on a range of expenditures for recipient households, using non-recipient households as a counterfactual for what recipient households' outcomes would have been in the absence of remittances. 
Formally, the estimated average treatment effect on the treated (ATT) can be derived as follows. Denote $T_{i}$ the treatment that equals 1 if the household $i$ receives remittances and 0 otherwise. The potential outcome of interest for household $i$ is $Y_{i 1}$ if household $i$ receives remittances and $Y_{i 0}$ otherwise. Given these definitions, the impact of the treatment $T_{i}$ on household $i$ is given by:

$$
\delta_{i}=Y_{i 1}-Y_{i 0}
$$

From this definition, the average treatment effect on the treated is defined as:

$$
A T T=E\left(Y_{1}-Y_{0} \mid T=1\right)
$$

Estimating this ATT poses an identification problem because $Y_{i 0}$, the non-treatment outcome of the treated group, cannot be observed directly for treated households and must be estimated. Matching methods offer a solution to estimate the counterfactual outcome for the treated group in the hypothetical absence of treatment, by pairing each treated household with a non-treated household that is similar in terms of its observed characteristics. Matching relies on the conditional independence assumption (CIA) or unconfoundedness assumption, which states that, conditional on a set of observable characteristics $X$, the treatment status is independent of potential outcomes:

$$
T_{i} \perp\left(Y_{i 1}, Y_{i 0}\right) \mid X_{i}
$$

Rosenbaum and Rubin (1983) have shown that if assignment to treatment is strongly ignorable given $X$, then assignment to treatment is also strongly ignorable given the propensity score $p(X)$, which means that we can reduce $X$ to one dimension and match on $p(X)$ instead.

\subsection{Implementation}

In practice, we first need to construct a statistical comparison group based on a model of the probability of participating in the treatment (i.e. receiving remittances), using a set of observed characteristics. Then, households that receive remittances are matched on the basis of this probability, or propensity score, to non-receiving households. The average treatment effect of the program can finally be calculated as the mean difference in outcomes across the two groups. 
Our main treatment is whether or not a household receives remittances in the year 2007. In this benchmark treatment, remittance-receiving households are matched to nonreceiving households, be they migrant-sending or non-migrant-sending households, and the estimated impact is that of remittances (whether they come from a household member or not). In order to refine the analysis, we also conduct separate analyses for the subtreatment of households who are both migrant-sending and remittance-receiving, and we match them alternatively to migrant households who do not receive remittances and to non-migrant households who do not receive remittances. The first match allows isolating the impact of remittances among migrant-sending households; the second match captures the joint effect of migration and remittances. As for the outcome variables, we consider successively different definitions of expenditure: total expenditure or consumption per capita; the expenditure shares of family business and of consumption; and the budget shares of various consumption components.

The first step of PSM analysis consists in estimating the propensity score with selected covariates. As recommended in the literature (Caliendo and Kopeinig, 2008), only variables that influence simultaneously the treatment status (i.e. receiving remittances) and the outcome variable (i.e. expenditure profile) should be included in this first step because unconfoundedness requires the outcome to be independent of treatment conditional on the propensity score. Moreover, only covariates that are unaffected by the treatment -hence, preferably observed prior to the treatment- should be included in the model so as to avoid endogeneity due to exposure to the treatment. Yet, Lechner (2008) argues that post-treatment variables may be included conditional on the fact that they are not systematically affected by the treatment. As our database is cross-sectional and does not contain any recall variables, we cannot select pre-treatment control variables to enter the propensity score estimate and we must rely on post-treatment variables. However, since we have information about each household member including migrants, incorporating migrants' information into our variables may reasonably help mitigate the potential endogeneity issue. Moreover, since large-scale migration is a recent phenomenon in China, it may limit the risk of a systematic influence of migration on household demographic characteristics (Bertoli and Marchetta, 2014).

Following papers that have recently applied the PSM approach to the analysis of migration and remittances on the left-behinds (Clément, 2011; Jimenez-Soto and Brown, 2012; Bertoli and Marchetta, 2014), we retain variables related to the household composition (including all members, either migrating or non-migrating), the education level of household adult members, the size of the migration network at the village level and 
provincial dummies that account for unobservables that could influence migration and consumption at the provincial level. We follow Bertoli and Marchetta (2014) and choose not to introduce household head characteristics in the covariates, as it is usually done in the literature, on the ground that household headship can be endogenous to migration. Similarly, household land holdings are excluded because they may respond to migration outcomes and therefore to remittance receipt ${ }^{5}$. Household composition variables include the number of adult members in the household, the share of children below the age of 6, the share of children aged between 6 and 15, the share of elderly (over the age of 65), the share of female adults, all variables that are shown in the economic literature to influence both the migration/remittances decision and household expenditure choice. The education level of household adult members is measured by the average education level of adult members and by a dummy indicating whether a member has ever completed higher education. As argued by Bertoli and Marchetta (2014), focusing on adult members should ensure that education decision has been taken independently of the receipt of remittances. In order to limit potential endogeneity concerns, household composition and educational attainment measures are computed on all household members, be they migrant or not. Our measure of migration network is the village share of households with migrants in 2005. As emphasized in the new economics of labour migration theory, migration networks are important pulling out forces, partly because the formation of a network reduces migration cost for new migrants (Massey et al., 1993). Table 5 displays the logit estimation used to generate the propensity score for the full sample and for the two sub-samples as described above. The overall goodness of fit measured by the pseudo $\mathrm{R}$ squared ranges between a low 0.086 for the comparison of remittance-receiving migrant households to non-remittance-receiving migrant households to a high 0.276 for the comparison of remittance-receiving migrant households to non-remittance-receiving non-migrant households.

The validity of PSM depends on several conditions. First, matching methods assume conditional independence, which means that conditional on observable variables $X$, the assignment to treatment is random, and the outcomes of non-treated units can be used to approximate the counterfactual outcome of treated units in the absence of treatment. Balancing tests allow checking whether observations with the same propensity score have the same distribution of covariates, independent of the assignment. Table 6 displays balancing tests for the main treatment (Column 1, Table 5), which check the equality of the means of the covariates in the model before and after matching, as well as the standardized

\footnotetext{
${ }^{5}$ We thank one of the referees for drawing our attention to concerns about potential endogeneity of land.
} 
bias before and after matching. It shows that after matching, the covariates are all well balanced between the treatment and the control groups (with a percent bias after matching less than 5\%). Another balancing check, proposed by Sianesi (2004), consists in comparing the pseudo $\mathrm{R}$ squared obtained from the logit model estimation on the matched and on the unmatched samples. If the balancing is effective, then the observed characteristics should explain very little of assignment to the treatment when estimated on the matched sample only. The pseudo $\mathrm{R}$ squared is much lower after matching (equal to 0.002 against 0.162 for the unmatched sample) and the likelihood-ratio test of the joint significance of all regressors is not rejected before matching ( $\mathrm{p}$-value of 0.000$)$, but rejected after matching (p-value of 0.447 ).

Second, a common support has to be imposed so as to reduce the bias in the estimate (Smith and Todd, 2005) and this restriction requires that the overlap in propensity scores across the participant and non-participant samples is sizeable. The comparison of the distributions of estimated propensity scores among recipient and non-recipient households (Figure 1, for the main treatment, as shown in Column 1, Table 5) shows large overlap, which indicates that observables that predict the probability of receiving remittances are distributed very similarly across the two groups.

The second step in PSM consists in using the estimated propensity scores to match each remittance-receiving household with its "nearest" non-receiving household. Various matching algorithms are available, and as discussed by Caliendo and Kopeinig (2008) each of them have their pros and cons. In this paper, we use a Kernel estimator that matches the outcome of each treated household to a weighted average of the outcomes of all the control households, assigning greatest weight to matched controls with the closest propensity score. One major advantage of kernel matching is the lower variance because more information is used. However, for the same reason, there could also be "bad matches" (Caliendo and Kopeinig, 2008) if outcomes with different propensity scores are matched. In what follows, we use a Gaussian Kernel matching procedure with a bandwidth parameter at 0.06 , and we impose common support in all the estimations. The average treatment effects on the treated (ATT) reported in Table 7 to Table 8 are derived from this procedure. 


\section{Results}

\subsection{Remittances and expenditure patterns}

Table 7 presents ATT estimates of receiving remittances for the entire sample on a set of various outcomes related to household expenditure and its composition. Concerning aggregate expenditure, our estimates indicate that both total per capita expenditure and per capita consumption significantly increase with receiving remittances. As far as the various components of total expenditure are concerned, Table 7 shows that receiving remittances is associated with a lower share of expenditure allocated to family business and in contrast, a higher share allocated to consumption. The negative gap between households that receive remittances and their non-receiving counterparts amounts to 2.84 percentage points for the expenditure share on family business, and the positive gap amounts to 3.72 percentage points for the expenditure share of consumption. These findings give support to the view that remittances supplement income in rural China and that they allow left behind families to increase consumption (de Brauw and Rozelle, 2008) when at the same time migration entails lower need and/or lower opportunities to develop ruralbased family productive activities. The significantly lower share of expenditure allocated to family business in remittance-receiving families may even suggest that the absence of working-age adult(s) in the household, due to migration, has a strong detrimental impact on the productive activities of the family, and that this detrimental impact more than compensates any potentially positive effect of remittances on easing the budget constraint of the left behinds and allowing them to invest in local family-run higher return activities.

Within consumption expenditures, two major components see their budget share increasing when the household receives remittances: expenses for durable goods and expenses for housing. By contrast, the budget share for education is significantly reduced whereas that for food and medical care are left unchanged. These findings consistently suggest that rural households in China favour investment in assets that immediately improve their quality of life (consumptive investment as defined by de Brauw and Rozelle (2008)) rather than in assets that increase their income-earning potential in the long run (productive investment), including investment in human capital.

Why do remittance recipients allocate a smaller share of their budget to education than non-recipients do whereas they have significantly more children aged 6 to 15? To understand this education puzzle, a first issue to investigate is whether receiving households spend less on education per child and/or whether children in receiving households 
tend to drop out of school more systematically. The RUMiC survey contains a module on the education of children that records useful information concerning the current education status of children and the cost of education ${ }^{6}$. As reported in the last row of Table 4, the amount of education spending per child strongly differs between remittance-receiving and non-receiving households: whereas non-receiving households spend on average 496.7 yuan per child for education purposes, receiving households spend only 325.5 yuan. A closer look at the distribution of children across various education levels reveals an interesting pattern: while there is no difference in educational attainment in primary and junior secondary school between remittance-receiving and non-receiving households, for children above the compulsory schooling (from senior high school), we observe a significant difference: 5.96 percent of non-receiving households have at least a child attending senior high school (or above) against 3.84 percent for remittance-receiving households. These figures suggest a seemingly different behaviour towards post-compulsory education between remittance-receiving families and non-receiving families, with migrant children dropping out earlier while non-migrant children stay longer. Since post-compulsory education is more expensive than compulsory education (mostly because most rural children have to go to boarding schools in post-compulsory education), this may explain why the budget share devoted to education is smaller for remittance-receiving households.

A second issue is why children in remittance-receiving households are more likely to drop out. One explanation found in the economic literature on China is that the returns to high school education acquired by rural residents in migrant labour markets in China are very low. de Brauw and Giles (2008) even show that the opportunity cost to enrol in high school in rural China is larger than the returns to education in migrant labour markets in cities. Hence, migrant labour markets are likely to exert a powerful pull on adolescents and signal low value of staying in school. In this context, the perceived benefits of education received in rural China may be so low that remittance-receiving households have no incentive to invest in human capital accumulation, and they rather choose to allocate remittances to alternative use (perceived as having higher and/or more immediate returns) and possibly send their children to join their migrant parent(s) and work in cities. A complementary explanation could be that migrant adult members are the more able in the family. The ones left behind are less likely to value education, and therefore less likely to spend on this particular expenditure component. This could be the case when migrants are parents who leave their children behind, under the care of (less educated) grand-parents.

\footnotetext{
${ }^{6}$ Education costs are split in several items: school regular fees (including tuition fees, accommodation and within school tutoring), extra-school tutoring fees, and other extra fees.
} 


\subsection{Migration, remittances and expenditure}

As discussed in Section 2, almost one-fifth of migrant households did not receive remittances in 2007 whereas 24 percent of remittance-receiving households in 2007 are not migrant-sending. In order to isolate the impact of remittances among migrant households, Specification (1) in Table 8 re-defines the treatment within the sub-sample of migrant households as remittance-receiving versus non-remittance-receiving. The estimated ATT are largely consistent with that of the full sample. Yet, three main findings are worth discussing. First, compared to the full sample, the positive impact on per capita expenditure and on per capita consumption is smaller in magnitude, but it is significant, showing that in migrant households, remittances do significantly contribute to increasing per capita expenditure and consumption. Second, the negative impact of remittances on the expenditure share on family business seems stronger in migrant households compared to the full sample. This finding corroborates the conjecture that migrant members may be positively selected on their ability, and that the absence of the most able members of the household further reduces investment in family business activities. Third, among migrant households, those receiving remittances spend a significantly higher share of their budget on housing, which adds evidence to the intuition that remittances are key inputs in housing investment in rural China.

The combined effect of migration and remittances on expenditure patterns is illustrated in Specification (2), which compares remittance-receiving migrant-sending households with non-remittance-receiving non-migrant-sending households. Unsurprisingly, the magnitude of the positive impact on per capita expenditure and per capita consumption is much larger when migrant households are compared only to non-migrant (non-receiving) households. Interestingly, the negative effect of migration and remittances on the education budget share is also larger in this setting, which confirms the net detrimental effect of migration on education.

\subsection{The heterogeneous impact of remittances}

In order to assess whether the impact of remittances is heterogeneous across different contexts, we further split our sample along two additional dimensions: the position of the household in the pre-transfer income distribution (by quartile), and whether the family left behind lives in a coastal or an inland province. Within each of the 6 new sub-samples, the treatment is whether or not a household receives remittances in the year 2007 (similar to 
the benchmark treatment for the full sample presented in Table 7). For each sub-sample, we estimate propensity scores, match households within the sub-sample, and estimate average treatment effects.

Table 9 displays the estimated ATT by pre-transfer income group and reveals noteworthy heterogeneity in the impact of remittances on consumption patterns. As far as aggregate expenditure is concerned, Table 9 first confirms the positive and significant impact of receiving remittances on per capita expenditure and per capita consumption. It also highlights that the increase is larger at the top of the pre-transfer income distribution. Hence, although households in the poorest quartiles are the most likely to receive remittances, in a larger amount (see Table 3), the per capita increase in consumption due to remittances is 1.3 times larger for receiving households in the fourth quartile than for receiving households in the first quartile.

In contrast with other income quartiles, the poorest households are clearly using migration as an additional source of income for the household. The substitution from expenses on family business to expenses on consumption when remittances are received is the highest for the first quartile, with a significant increase in the share of expenditure on consumption associated with remittances as high as 4.68 percentage points and a concomitant decrease in the share of expenditure on family business as high as 4.43 percentage points. The detrimental effect of migration on the productive activities of the family highlighted for the full sample thus seems to come mostly from the poorest households and to hurt them the most. Moreover, the analysis of the budget shares indicates that in the first quartile, remittance-receiving households do not use private transfers from migrants differently from other sources of income, but instead take them as a component in the pooled household income. Although remittances constitute an important share of total income for the poorest group of households before transfer (Table 3), these transfers do not seem to alter much the consumption behaviour in this group. Indeed, the consumption pattern of the poorest quartile is not significantly different between remittance-receiving and non-receiving households. The only, notable, exception is the budget share for durable goods that appears significantly increased by 1.94 percentage points when the household receives remittances. Receiving remittances allows households in the first quartile to spend on these goods almost as much of their budget as average households in the third quartile ${ }^{7}$.

Similar "moves" towards average households in above quartiles are also observed for

\footnotetext{
${ }^{7}$ The budget share for durable goods amounts to $14.9 \%$ on average for the third quartile, and to $12.2 \%$ on average for the first quartile (see Table 3).
} 
remittance-receiving households in the second and the third quartiles. For instance, remittance-receiving households in the second quartile exhibit a significantly lower budget share for food and conversely a significantly higher budget share for durable goods. Both changes make their budget shares for these items closer to the average budget share of households in the third quartile (as displayed in Table 3). Similarly, remittance-receiving households in the third quartile get closer to the average household in the fourth quartile in terms of food, durable goods and housing budget shares.

Interestingly, the type of consumptive investment favoured by remittance-receiving households also varies across quartiles: whereas the budget share for durable goods significantly increases when households receive remittances in the first, second and third quartiles, it is the budget share for housing that significantly increases when households receive remittances at the top of the pre-transfer income distribution. As far as housing consumption is concerned, receiving remittances results in a 1.75 percentage points increase of the budget share allocated to housing in the top two quartiles. Since the average budget share of housing for the third and fourth quartiles amounts respectively to $11.1 \%$ and $12.8 \%$ (Table 3 ), these are sizeable effects. The positive impact of remittances on housing budget shares for wealthier households may be interpreted in various ways. First, housing investment may be used by wealthier remittance-receiving households as a signal of migrants' resources and support to their home family (Osili, 2004). In a similar vein, it could be that remittance-senders impose conditions on the type of use of their transfers by their family, and that they secure their position at home in the event of future return precisely by investing in housing. In the case of China, both explanations may hold, especially because migrants maintain strong economic and social ties to their village, and because a large share eventually returns. Under the standard investment explanation, another interpretation as to why remittance-receiving households privilege investment in housing could be that housing investment yields higher rates of return compared to alternative investment, including in human capital (Osili, 2004). Finally, the positive impact of remittances on housing budget shares could also reveal persisting difficulties in various markets in rural areas in China, despite the accelerating economic growth and reforms during the 2000s. Referring to the end of the 1990s, de Brauw and Rozelle (2008) argued that housing investment was constrained in rural areas. The 2000s have witnessed a strong development of the real estate sector in China, but our results suggest that housing investment in rural China might still be largely constrained.

In the top quartiles, remittance-receiving households are not only characterized by a different type of consumptive investment (towards housing rather than durable goods), 
they are also characterized by reduced productive investment, through a significant reduction in their budget share for education relative to other households. Hence, the overall negative impact of remittances on the budget share allocated to education found in the full sample (Table 7) seem to be mostly attributable to the top two quartiles. Receiving remittances does not significantly affect the budget share allocated to education in the first two quartiles, whereas it results in a 1.60 percentage points decrease in the third quartile, and a 2.16 percentage points decrease in the fourth quartile. In these top quartiles, remittance-receiving households spend on education as little of their budget as average households in the lowest quartile $(6.10 \%$, see Table 3$)$.

Table 10 provides additional insights into the heterogeneous effect of remittances by location. Separate estimations for coastal and for inland provinces exhibit patterns that are generally close to each other. Yet, they highlight an interesting feature regarding the non-use of remittances for productive investment in rural China. One could reasonably expect that coastal areas in China offer more opportunities for rural households to invest in productive activities, and therefore they could use migration as a means to finance such activities. The estimated ATT displayed in Table 10 suggest that migration does not play such a role in rural coastal areas: the reduction in the share of expenditure on family business (by 3.17 percentage points) and the increase in the share of expenditure on consumption (by 4.86 percentage points) associated with remittances are even larger in coastal provinces than in the aggregate estimates and than in inland provinces (respectively 3.08 and 3.54 percentage points). Hence, it could be the case that even in coastal provinces, migrant-sending households are not those most likely to start local business activities or to invest much in agriculture. Such interpretation corroborates de Brauw and Rozelle (2008)'s conclusions.

\section{Conclusion}

This paper explores how private transfers from internal migration in China affect the expenditure behaviour of left behind families in rural areas using cross-sectional data on rural households for the year 2007. Our main findings indicate that remittances from internal migration supplement income in rural China and increase per capita consumption. As they represent a large share of income for the poorest households, remittances may help mitigate the exposure to poverty for the most vulnerable. Regarding the budget allocation pattern of rural households, the key results are twofold. First, remittance-recipient households are found to spend more on consumption-type expenditures and less on pro- 
ductive investment. These findings from a large-scale recent dataset are consistent with what has been observed on small-scale databases for the end of the 1990s and the early 2000s (de Brauw and Rozelle, 2008; Zhu et al., 2012, 2014). Yet, with the accelerating economic growth and labour mobility in China during the 2000s, the persistence of a consumption use of remittances may signal persisting difficulties in various markets in rural areas. Second, within their budget for living expenses, remittance-receiving households are found to favor investment in assets that immediately improve their quality of life, such as housing or durable goods. By contrast, they reduce their budget share allocated to education, and this effect holds in particular for the wealthiest groups of households. These findings sharply contrast with the positive effect of remittances on investment of families left behind found in other developing countries. This is the case for instance in the Philippines where Yang (2008) shows that remittances are positively associated with human capital investment and investment in more capital-intensive household enterprises.

The strong evidence of a negative impact of remittances on education budget share found here points to the ambiguous perception of skill premium in China, notably in the migrant labour market, and can be illustrative of the low perceived returns to education in this particular labour market. It may also signal a lower value put on education by the (less educated) rural left-behinds (e.g. grand-parents). Whatever the interpretation, this finding points to the potentially strong detrimental impact of migration on rural areas since education is a primary vehicle for poverty alleviation and also a vector for sustaining economic growth through a middle income class. A straightforward implication is the need for carefully designed education policies in rural areas, which would not only broaden the access to non-compulsory education, but also ensure that the quality of both compulsory and post-compulsory education meets the expected standard on the urban labour market. 


\section{References}

Acosta, P., Calderon, C., Fajnzylber, P., and Lopez, H. (2008). What is the impact of international remittances on poverty and inequality in Latin America? World Development, 36(1):89-114.

Adams, R. (1998). Remittances, investment, and rural asset accumulation in Pakistan. Economic Development and Cultural Change, 47(1):155-73.

Adams, R. H. and Cuecuecha, A. (2010). Remittances, Household Expenditure and Investment in Guatemala. World Development, 38(11):1626-1641.

Adams, R. H. and Cuecuecha, A. (2013). The Impact of Remittances on Investment and Poverty in Ghana. World Development, 50:24-40.

Adams, R. H., Cuecuecha, A., and Page, J. (2008). Remittances, consumption and investment in ghana. World Bank Policy Research Working Paper No. 4515.

Akgüc, M., Giulietti, C., and Zimmermann, K. (2014). The RUMiC longitudinal survey: fostering research on labor markets in China. IZA Journal of Labor and Development, $3(1): 1-14$.

Alcaraz, C., Chiquiar, D., and Salcedo, A. (2012). Remittances, schooling, and child labor in Mexico. Journal of Development Economics, 97(1):156-165.

Amuedo-Dorantes, C. and Pozo, S. (2011). New evidence on the role of remittances on healthcare expenditures by Mexican households. Review of Economics of the Household, 9(1):69-98.

Antman, F. (2012). Gender, educational attainment, and the impact of parental migration on children left behind. Journal of Population Economics, 25(4):1187-1214.

Antman, F. (2013). The impact of migration on family left behind. In Constant, A. and Zimmermann, K., editors, International Handbook on the Economics of Migration, pages $293-308$.

Bertoli, S. and Marchetta, F. (2014). Migration, remittances and poverty in Ecuador. The Journal of Development Studies, 50(8):1067-1089.

Böhme, M. H. (2015). Migration and educational aspirations âĂŞ another channel of brain gain? IZA Journal of Migration, 4(12):1-24.

Caliendo, M. and Kopeinig, S. (2008). Some practical guidance for the implementation of propensity score matching. Journal of Economic Surveys, 22(1):31-72.

Cardona-Sosa, L. and Medina, C. (2006). Migration as a safety net and effects of remittances on household consumption: The case of Colombia. Economic unit, Banco de la Republica, Colombia.

Castaldo, A. and Reilly, B. (2007). Do migrant remittances affect the consumption patterns of Albanian households? South-Eastern Europe Journal of Economics, 5(1):25-54.

Cattaneo, C. (2012). Migrants' international transfers and educational expenditure Empirical evidence from Albania. Economics of Transition, 20(1):163-193.

Cheng, E. and Xu, Z. (2005). Domestic money transfer services for rural migrant workers in China. Microfinance Gateway, Consultative Group to Assist the Poor (CGAP), Washington D.C. 
Clément, M. (2011). Remittances and household expenditure patterns in Tajikistan: A propensity score matching analysis. Asian Development Review, 28(2):58-87.

de Brauw, A. and Giles, J. (2008). Migrant opportunity and the educational attainment of youth in rural China. Policy Research Working Paper 4526, Washington DC, The World Bank.

de Brauw, A. and Rozelle, S. (2008). Migration and household investment in rural China. China Economic Review, 19(2):320-335.

Démurger, S. and Li, S. (2013). Migration, remittances and rural employment patterns: Evidence from China. Research in Labor Economics, 37:31-63.

Démurger, S. and $\mathrm{Xu}, \mathrm{H}$. (2015). Left-behind children and return migration in China. IZA Journal of Migration, 4(10):1-21.

Giannelli, G. C. and Mangiavacchi, L. (2010). Children's schooling and parental migration: Empirical evidence on the 'left-behind' generation in Albania. LABOUR, 24:76-92.

Göbel, K. (2013). Remittances, expenditure patterns, and gender: parametric and semiparametric evidence from ecuador. IZA Journal of Migration, 2(1):1-19.

Hu, F. and Shi, Y. (2013). Remittances from rural migrants and the development of the migrant-sending areas. World Economic Papers, 2:In Chinese.

Jimenez-Soto, E. and Brown, R. P. C. (2012). Assessing the poverty impacts of migrants' remittances using propenssty score matching: The case of Tonga. The Economic Record, 88(282):425-439.

Kifle, T. (2007). Do remittances encourage investment in education? Evidence from Eritrea. GEFAME Journal of African Studies, 4(1).

Lechner, M. (2008). A note on endogenous control variables in causal studies. Statistics and Probability Letters, 78(2):190-195.

Mao, R. and Xu, J. (2014). Population aging, consumption budget allocation and sectoral growth. China Economic Review, 30(0):44 - 65.

Massey, D., Arango, J., Hugo, G., Kouaouci, A., Pellegrino, A., and Taylor, J. (1993). Theories of international migration: A review and appraisal. Population and Development Review, 19(3):431-466.

McKenzie, D., Gibson, J., and Stillman, S. (2010). How important is selection? Experimental versus non-experimental measures of the income gains from migration. Journal of the European Economic Association, 8(4):913-945.

McKenzie, D. and Rapoport, H. (2011). Can migration reduce educational attainment? evidence from Mexico. Journal of Population Economics, 24(4):1-21.

Meng, X., Manning, C., Li, S., and Effendi, T. N. (2010). The Great Migration: RuralUrban Migration in China and Indonesia. Edward Elgard, Cheltenham.

Osili, U. O. (2004). Migrants and Housing Investments: Theory and Evidence from Nigeria. Economic Development and Cultural Change, 52(4):821-49.

Rosenbaum, P. R. and Rubin, D. B. (1983). The central role of the propensity score in observational studies for causal effects. Biometrika, 70(1):41-55. 
Sianesi, B. (2004). An evaluation of the swedish system of active labor market programs in the 1990s. The Review of Economics and Statistics, 86(1):133-155.

Smith, J. A. and Todd, P. E. (2005). Does matching overcome lalonde's critique of nonexperimental estimators? Journal of Econometrics, 125(1-2):305-353.

Taylor, E. and Mora, J. (2006). Does Migration Reshape Expenditures In Rural Households? Evidence From Mexico. The World Bank.

Yang, D. (2008). International migration, remittances and household investment: Evidence from Philippine migrants' exchange rate shocks. The Economic Journal, 118:591630 .

Zhang, H., Behrman, J. R., Fan, C. S., Wei, X., and Zhang, J. (2014). Does parental absence reduce cognitive achievements? evidence from rural China. Journal of Development Economics, 111:181-195.

Zhu, Y., Wu, Z., Peng, L., and Sheng, L. (2014). Where did all the remittances go? Understanding the impact of remittances on consumption patterns in rural China. Applied Economics, 46(12):1312-1322.

Zhu, Y., Wu, Z., Wang, M., Du, Y., and Cai, F. (2012). Do migrants really save more? understanding the impact of remittances on savings in rural China. Journal of Development Studies, 48(5):654-672. 
Table 1: Summary statistics by remittance status - Household characteristics, 2007

\begin{tabular}{|c|c|c|c|c|}
\hline & $\begin{array}{l}\text { Non-receiving } \\
\text { households }\end{array}$ & $\begin{array}{c}\text { Remittance-receiving } \\
\text { households }\end{array}$ & $\begin{array}{l}\text { All } \\
\text { households }\end{array}$ & $\begin{array}{l}\text { Difference } \\
\text { in means }\end{array}$ \\
\hline Household size (excl. migrants) & $\begin{array}{c}3.411 \\
(1.279)\end{array}$ & $\begin{array}{c}3.103 \\
(1.225)\end{array}$ & $\begin{array}{c}3.262 \\
(1.262)\end{array}$ & $* * *$ \\
\hline Household size (incl. migrants) & $\begin{array}{c}3.640 \\
(1.302)\end{array}$ & $\begin{array}{c}4.355 \\
(1.343)\end{array}$ & $\begin{array}{c}3.987 \\
(1.369)\end{array}$ & $* * *$ \\
\hline \# adult members & $\begin{array}{c}3.064 \\
(1.063)\end{array}$ & $\begin{array}{c}3.691 \\
(1.150)\end{array}$ & $\begin{array}{l}3.368 \\
(1.149)\end{array}$ & $* * *$ \\
\hline Dependent over 65 in household & $\begin{array}{c}0.127 \\
(0.333)\end{array}$ & $\begin{array}{c}0.106 \\
(0.307)\end{array}$ & $\begin{array}{c}0.117 \\
(0.321)\end{array}$ & $* * *$ \\
\hline Infants in household & $\begin{array}{c}0.117 \\
(0.321)\end{array}$ & $\begin{array}{c}0.195 \\
(0.396)\end{array}$ & $\begin{array}{c}0.155 \\
(0.362)\end{array}$ & $* * *$ \\
\hline Children in household & $\begin{array}{c}0.462 \\
(0.499)\end{array}$ & $\begin{array}{c}0.545 \\
(0.498)\end{array}$ & $\begin{array}{c}0.502 \\
(0.500)\end{array}$ & $* * *$ \\
\hline $\begin{array}{l}\text { Average education of adult members } \\
\text { (years) }\end{array}$ & $\begin{array}{l}6.888 \\
(2.414)\end{array}$ & $\begin{array}{c}7.079 \\
(1.925)\end{array}$ & $\begin{array}{l}6.980 \\
(2.193)\end{array}$ & $* * *$ \\
\hline Coast & $\begin{array}{c}0.552 \\
(0.497)\end{array}$ & $\begin{array}{c}0.319 \\
(0.466)\end{array}$ & $\begin{array}{c}0.439 \\
(0.496)\end{array}$ & $* * *$ \\
\hline Centre & $\begin{array}{c}0.307 \\
(0.461)\end{array}$ & $\begin{array}{c}0.416 \\
(0.493)\end{array}$ & $\begin{array}{c}0.360 \\
(0.480)\end{array}$ & $* * *$ \\
\hline West & $\begin{array}{c}0.141 \\
(0.348)\end{array}$ & $\begin{array}{c}0.265 \\
(0.441)\end{array}$ & $\begin{array}{c}0.201 \\
(0.401)\end{array}$ & $* * *$ \\
\hline Observations & 3958 & 3724 & 7682 & \\
\hline
\end{tabular}

Notes: The last column displays the significance level of mean differences between remittance-receiving and non-receiving households (NS: non-significant; *: significant at 10\%; **: significant at $5 \%$; ***: significant at 1\%). The regional classification is the following: Coast includes Hebei, Jiangsu, Zhejiang and Guangdong provinces; Centre includes Henan, Hubei and Anhui provinces, and West includes Chongqing municipality and Sichuan province. Source: RUMiC Rural Household Survey 2007. 
Table 2: Summary statistics by remittance status - Income and expenditures, 2007

\begin{tabular}{|c|c|c|c|c|}
\hline Unit: Yuan & $\begin{array}{c}\text { Non-receiving } \\
\text { households }\end{array}$ & $\begin{array}{c}\text { Remittance-receiving } \\
\text { households }\end{array}$ & $\begin{array}{c}\text { All } \\
\text { households }\end{array}$ & $\begin{array}{l}\text { Difference } \\
\text { in means }\end{array}$ \\
\hline Total net income & $\begin{array}{c}19661.4 \\
(19044.2)\end{array}$ & $\begin{array}{c}19157.1 \\
(11767.2)\end{array}$ & $\begin{array}{c}19416.9 \\
(15938.0)\end{array}$ & NS \\
\hline Per capita net income (including migrants) & $\begin{array}{c}5739.5 \\
(5263.8)\end{array}$ & $\begin{array}{c}4641.1 \\
(2799.6)\end{array}$ & $\begin{array}{c}5207.0 \\
(4286.6)\end{array}$ & $* * *$ \\
\hline Per capita net income (excluding migrants) & $\begin{array}{c}6185.9 \\
(5793.3)\end{array}$ & $\begin{array}{l}7129.7 \\
(5266.3)\end{array}$ & $\begin{array}{c}6643.4 \\
(5563.8)\end{array}$ & $* * *$ \\
\hline Per capita expenditure & $\begin{array}{c}6965.0 \\
(8458.8)\end{array}$ & $\begin{array}{l}7118.0 \\
(5978.0)\end{array}$ & $\begin{array}{c}7039.2 \\
(7361.3)\end{array}$ & NS \\
\hline Per capita consumption & $\begin{array}{c}4487.8 \\
(3853.2)\end{array}$ & $\begin{array}{l}5100.0 \\
(4691.7)\end{array}$ & $\begin{array}{c}4784.6 \\
(4290.9)\end{array}$ & $* * *$ \\
\hline \multicolumn{5}{|l|}{ Household income composition } \\
\hline Net income from wages & $\begin{array}{c}7087.2 \\
(10373.8)\end{array}$ & $\begin{array}{l}10719.2 \\
(9563.3)\end{array}$ & $\begin{array}{c}8847.9 \\
(10152.1)\end{array}$ & $* * *$ \\
\hline of which: Net wage income from local off-farm & $\begin{array}{c}5962.9 \\
(9434.6)\end{array}$ & $\begin{array}{c}1775.0 \\
(3461.5)\end{array}$ & $\begin{array}{c}3932.7 \\
(7486.3)\end{array}$ & $* * *$ \\
\hline of which: Remittances & 0 & $\begin{array}{c}8458.7 \\
(8362.3)\end{array}$ & $\begin{array}{c}4100.5 \\
(7194.9)\end{array}$ & $* * *$ \\
\hline Net income from family farm operation & $\begin{array}{c}6773.6 \\
(10728.0)\end{array}$ & $\begin{array}{c}6593.8 \\
(5718.2)\end{array}$ & $\begin{array}{c}6686.5 \\
(8668.7)\end{array}$ & NS \\
\hline Net income from family off-farm operation & $\begin{array}{c}3685.8 \\
(11523.2)\end{array}$ & $\begin{array}{c}899.7 \\
(3538.9)\end{array}$ & $\begin{array}{c}2335.2 \\
(8741.6)\end{array}$ & $* * *$ \\
\hline Net property income & $\begin{array}{c}1033.0 \\
(8134.0)\end{array}$ & $\begin{array}{c}275.0 \\
(1435.2)\end{array}$ & $\begin{array}{c}665.6 \\
(5935.2)\end{array}$ & $* * *$ \\
\hline Net transfer income & $\begin{array}{c}1081.8 \\
(3649.3)\end{array}$ & $\begin{array}{c}669.2 \\
(2280.6)\end{array}$ & $\begin{array}{c}881.8 \\
(3069.9)\end{array}$ & $* * *$ \\
\hline Observations & 3958 & 3724 & 7682 & \\
\hline
\end{tabular}

Notes: Standard deviations in parentheses. The last column displays the significance level of mean differences between remittance-receiving and non-receiving households (NS: non-significant; *: significant at 10\%; ***: significant at 1\%). Source: RUMiC Rural Household Survey 2007. 
Table 3: Distribution of households and amount of remittances across pre-transfer income quartiles, 2007

\begin{tabular}{|c|c|c|c|c|c|}
\hline & $1^{\text {st }}$ quartile & $2^{\text {nd }}$ quartile & $3^{\text {rd }}$ quartile & $4^{\text {th }}$ quartile & Total \\
\hline$\%$ of households & & & & & Obs. \\
\hline Remittance-receiving & 36.31 & 29.40 & 23.07 & 11.22 & 3724 \\
\hline Non remittance-receiving & 14.58 & 21.00 & 26.91 & 37.52 & 3958 \\
\hline Average amount of remittances (yuan) & $\begin{array}{c}6296.7 \\
(7428.3)\end{array}$ & $\begin{array}{c}4470.2 \\
(7107.8)\end{array}$ & $\begin{array}{c}3581.7 \\
(6779.4)\end{array}$ & $\begin{array}{c}2024.6 \\
(6775.5)\end{array}$ & $\begin{array}{c}4100.5 \\
(7194.9)\end{array}$ \\
\hline Total net income (yuan) & $\begin{array}{l}10576.4 \\
(7760.1)\end{array}$ & $\begin{array}{l}13763.3 \\
(7186.0)\end{array}$ & $\begin{array}{l}18493.9 \\
(6937.6)\end{array}$ & $\begin{array}{c}35033.3 \\
(22524.8)\end{array}$ & $\begin{array}{c}19416.9 \\
(15938.0)\end{array}$ \\
\hline Per capita net income (yuan) & $\begin{array}{c}4459.5 \\
(4208.6)\end{array}$ & $\begin{array}{c}5078.2 \\
(3575.1)\end{array}$ & $\begin{array}{c}6268.3 \\
(3573.2)\end{array}$ & $\begin{array}{l}10820.4 \\
(7502.9)\end{array}$ & $\begin{array}{c}6643.4 \\
(5563.8)\end{array}$ \\
\hline \multicolumn{6}{|l|}{ Total expenditure } \\
\hline Share of exp. on family business & $\begin{array}{c}0.242 \\
(0.170)\end{array}$ & $\begin{array}{c}0.237 \\
(0.161)\end{array}$ & $\begin{array}{c}0.214 \\
(0.174)\end{array}$ & $\begin{array}{c}0.185 \\
(0.196)\end{array}$ & $\begin{array}{c}0.219 \\
(0.177)\end{array}$ \\
\hline Share of exp. on consumption & $\begin{array}{c}0.707 \\
(0.175)\end{array}$ & $\begin{array}{c}0.706 \\
(0.169)\end{array}$ & $\begin{array}{c}0.723 \\
(0.185)\end{array}$ & $\begin{array}{c}0.744 \\
(0.207)\end{array}$ & $\begin{array}{c}0.720 \\
(0.185)\end{array}$ \\
\hline \multicolumn{6}{|l|}{ Budget shares for consumption expenses } \\
\hline Budget share for food & $\begin{array}{c}0.646 \\
(0.153)\end{array}$ & $\begin{array}{c}0.625 \\
(0.162)\end{array}$ & $\begin{array}{c}0.604 \\
(0.161)\end{array}$ & $\begin{array}{c}0.569 \\
(0.166)\end{array}$ & $\begin{array}{c}0.611 \\
(0.163)\end{array}$ \\
\hline Budget share for durable goods & $\begin{array}{c}0.122 \\
(0.0920)\end{array}$ & $\begin{array}{c}0.136 \\
(0.0979)\end{array}$ & $\begin{array}{c}0.149 \\
(0.101)\end{array}$ & $\begin{array}{c}0.161 \\
(0.101)\end{array}$ & $\begin{array}{c}0.142 \\
(0.0991)\end{array}$ \\
\hline Budget share for housing & $\begin{array}{l}0.103 \\
(0.109)\end{array}$ & $\begin{array}{c}0.112 \\
(0.127)\end{array}$ & $\begin{array}{c}0.111 \\
(0.123)\end{array}$ & $\begin{array}{c}0.128 \\
(0.146)\end{array}$ & $\begin{array}{l}0.114 \\
(0.127)\end{array}$ \\
\hline Budget share for education & $\begin{array}{c}0.0610 \\
(0.0910)\end{array}$ & $\begin{array}{c}0.0694 \\
(0.0984)\end{array}$ & $\begin{array}{l}0.0786 \\
(0.106)\end{array}$ & $\begin{array}{l}0.0878 \\
(0.121)\end{array}$ & $\begin{array}{l}0.0742 \\
(0.105)\end{array}$ \\
\hline Budget share for medical care & $\begin{array}{c}0.0676 \\
(0.0919)\end{array}$ & $\begin{array}{c}0.0580 \\
(0.0830)\end{array}$ & $\begin{array}{c}0.0575 \\
(0.0856)\end{array}$ & $\begin{array}{c}0.0542 \\
(0.0870)\end{array}$ & $\begin{array}{c}0.0593 \\
(0.0870)\end{array}$ \\
\hline
\end{tabular}

Notes: Expenditures on family business and on consumption do not sum up to $100 \%$ because "other expenditures" (including taxes and fees, expenses on properties and on transfers) are not reported here. Standard deviations in parentheses. Source: RUMiC Rural Household Survey 2007. 
Table 4: Budget shares by remittance-receiving status, 2007

\begin{tabular}{lcccc}
\hline \hline & $\begin{array}{c}\text { Non-receiving } \\
\text { households }\end{array}$ & $\begin{array}{c}\text { Remittance-receiving } \\
\text { households }\end{array}$ & $\begin{array}{c}\text { All } \\
\text { households }\end{array}$ & $\begin{array}{c}\text { Difference } \\
\text { in means }\end{array}$ \\
\hline $\begin{array}{l}\text { Total expenditure } \\
\text { Share of exp. on family business }\end{array}$ & 0.214 & 0.224 & 0.219 & $* * *$ \\
Share of exp. on consumption & 0.716 & 0.724 & 0.720 & $* *$ \\
$\begin{array}{l}\text { Total consumption } \\
\text { Budget share for food }\end{array}$ & 0.606 & 0.616 & 0.611 & $* * *$ \\
Budget share for durable goods & 0.141 & 0.144 & 0.142 & $*$ \\
Budget share for housing & 0.112 & 0.115 & 0.114 & NS \\
Budget share for education & 0.0812 & 0.0668 & 0.0742 & $* * *$ \\
Budget share for medical care & 0.0602 & 0.0583 & 0.0593 & NS \\
Per child education expenditure (yuan) & 496.7 & 325.5 & 413.7 & $* * *$ \\
\hline Observations & 3958 & 3724 & 7682 & \\
\hline \hline
\end{tabular}

Notes: Expenditures on family business and on consumption do not sum up to $100 \%$ because "other expenditures" (including taxes and fees, expenses on properties and on transfers) are not reported here. The last column displays the significance level of mean differences between remittance-receiving and non-receiving households (NS: non-significant; *: significant at $10 \%$; $* *$ : significant at $5 \%$; ***: significant at 1\%). Source: RUMiC Rural Household Survey 2007. 
Table 5: Logit estimation for propensity score

Dependent variable: whether the household receives remittances

(1)

$(2)$

(3)

\begin{tabular}{lccc} 
\# adult members & $0.602^{* * *}(0.0275)$ & $0.962^{* * *}(0.0367)$ & $0.150^{* * *}(0.0517)$ \\
Share of children $<6$ & $1.574^{* * *}(0.320)$ & $1.272^{* * *}(0.400)$ & $2.148^{* * *}(0.650)$ \\
Share of children 6-15 & $1.209^{* * *}(0.185)$ & $1.685^{* * *}(0.231)$ & $0.836^{* *}(0.378)$ \\
Share of elderly $(>65)$ & $-1.847^{* * *}(0.296)$ & $-3.135^{* * *}(0.407)$ & $-1.136^{* *}(0.549)$ \\
Share of female adults & $-0.550^{* * *}(0.189)$ & $-1.306^{* * *}(0.236)$ & $0.192(0.324)$ \\
Average education & $0.0484^{* * *}(0.0131)$ & $0.0863^{* * *}(0.0165)$ & $0.0107(0.0271)$ \\
Tertiary education of adults & $-0.395^{* * *}(0.0916)$ & $-0.288^{* *}(0.112)$ & $-0.536^{* * *}(0.141)$ \\
Migration network & $3.115^{* * *}(0.244)$ & $4.552^{* * *}(0.312)$ & $2.319^{* * *}(0.445)$ \\
Hebei & $-0.0971(0.126)$ & $-0.512^{* * *}(0.165)$ & $-0.788^{* * *}(0.255)$ \\
Jiangsu & $0.179^{*}(0.102)$ & $0.300^{* *}(0.119)$ & $-0.334^{*}(0.191)$ \\
Zhejiang & $-1.232^{* * *}(0.124)$ & $-1.606^{* * *}(0.169)$ & $-2.139^{* * *}(0.221)$ \\
Anhui & $0.503^{* * *}(0.104)$ & $0.734^{* * *}(0.125)$ & $-0.451^{* *}(0.180)$ \\
Henan & $0.380^{* * *}(0.0991)$ & $0.232^{*}(0.122)$ & $-0.588^{* * *}(0.184)$ \\
Hubei & $0.866^{* * *}(0.102)$ & $1.023^{* * *}(0.121)$ & $-0.0757(0.180)$ \\
Chongqing & $1.010^{* * *}(0.126)$ & $0.938^{* * *}(0.159)$ & $-0.519^{* *}(0.218)$ \\
Sichuan & $1.009^{* * *}(0.102)$ & $1.051^{* * *}(0.120)$ & $0.212(0.194)$ \\
Constant & $-3.093^{* * *}(0.185)$ & $-4.641^{* * *}(0.237)$ & $0.559(0.367)$ \\
\hline Observations & 7682 & 6000 & 3346 \\
Pseudo R & 0.163 & 0.276 & 0.0857 \\
\hline \hline
\end{tabular}

Notes: Specification (1) includes all households in the sample. Specification (2) is based on the sub-sample of migrant-sending remittance-receiving households and non-migrant-sending non-remittance-receiving households. Specification (3) is based on the sub-sample of migrant-sending households. Migration network is measured by the village share of households with migrants in 2005. Standard errors in parentheses. ${ }^{*} p<0.10,{ }^{* *} p<0.05,{ }^{* * *} p<0.01$. Source: RUMiC Rural Household Survey 2007. 
Table 6: Balancing tests for propensity score matching

\begin{tabular}{|c|c|c|c|c|c|}
\hline \multirow[t]{2}{*}{ Variable } & \multirow{2}{*}{ Sample } & \multicolumn{2}{|c|}{ Mean } & \multirow[t]{2}{*}{$\%$ bias } & \multirow[t]{2}{*}{$\%$ reduction in bias } \\
\hline & & Treated & Control & & \\
\hline \multirow[t]{2}{*}{$\#$ adult members } & Unmatched & 3.6907 & 3.0642 & 56.6 & \\
\hline & Matched & 3.5961 & 3.5512 & 4.1 & 92.8 \\
\hline \multirow[t]{2}{*}{ Share of children } & Unmatched & .03969 & .02622 & 16.9 & \\
\hline & Matched & .03779 & .03579 & 2.5 & 85.2 \\
\hline \multirow[t]{2}{*}{ Share of children } & Unmatched & .09944 & .10702 & -5.0 & \\
\hline & Matched & .10153 & .10595 & -2.9 & 41.5 \\
\hline \multirow{2}{*}{ Share of elderly $(>65)$} & Unmatched & .02577 & .04248 & -14.6 & \\
\hline & Matched & .02632 & .02824 & -1.7 & 88.5 \\
\hline \multirow{2}{*}{ Share of female adults } & Unmatched & .48416 & .48827 & -3.0 & \\
\hline & Matched & .48402 & .48347 & 0.4 & 86.5 \\
\hline \multirow{2}{*}{ Average education } & Unmatched & 7.0788 & 6.8876 & 8.8 & \\
\hline & Matched & 7.0621 & 7.0706 & -0.4 & 95.6 \\
\hline \multirow{2}{*}{ Tertiary education of adults } & Unmatched & .09291 & .10687 & -4.7 & \\
\hline & Matched & .09412 & .09868 & -1.5 & 67.3 \\
\hline \multirow{2}{*}{ Migration network } & Unmatched & .20775 & .14182 & 41.5 & \\
\hline & Matched & .1905 & .18487 & 3.5 & 91.5 \\
\hline \multirow[t]{2}{*}{ Hebei } & Unmatched & .0427 & .08186 & -16.3 & \\
\hline & Matched & .04494 & .04887 & -1.6 & 90.0 \\
\hline \multirow[t]{2}{*}{ Jiangsu } & Unmatched & .10929 & .143 & -10.2 & \\
\hline & Matched & .10967 & .1032 & 2.0 & 80.8 \\
\hline \multirow[t]{2}{*}{ Zhejiang } & Unmatched & .03249 & .20465 & -55.2 & \\
\hline & Matched & .0342 & .03877 & -1.5 & 97.3 \\
\hline \multirow[t]{2}{*}{ Anhui } & Unmatched & .1297 & .09247 & 11.9 & \\
\hline & Matched & .1286 & .12602 & 0.8 & 93.1 \\
\hline \multirow[t]{2}{*}{ Henan } & Unmatched & .12352 & .12506 & -0.5 & \\
\hline & Matched & .12889 & .13773 & -2.7 & -474.3 \\
\hline \multirow[t]{2}{*}{ Hubei } & Unmatched & .16273 & .08969 & 22.1 & \\
\hline & Matched & .15659 & .15761 & -0.3 & 98.6 \\
\hline \multirow[t]{2}{*}{ Chongqing } & Unmatched & .08324 & .04497 & 15.7 & \\
\hline & Matched & .08112 & .08447 & -1.4 & 91.2 \\
\hline \multirow[t]{2}{*}{ Sichuan } & Unmatched & .18179 & .09626 & 24.9 & \\
\hline & Matched & .1792 & .1687 & 3.1 & 87.7 \\
\hline
\end{tabular}

Notes: The balancing test refers to the benchmark specification of the propensity score with all remittance-receiving households included in the treatment group no matter their migration status (specification (1) in Table 5). Migration network is measured by the village share of households with migrants in 2005. Standard errors in parentheses. Source: RUMiC Rural Household Survey 2007. 
Table 7: Average treatment effects - Full sample

\begin{tabular}{rccccc}
\hline \hline & Treated group & Control group & Difference & Standard error & Significance \\
\hline Per capita expenditure & 7165 & 6008 & 1157 & 208 & $* * *$ \\
Per capita consumption & 5142 & 3726 & 1416 & 115 & $* * *$ \\
& & & & & \\
Total expenditure & & & & & $*$ \\
Share of exp. on family business & 0.2234 & 0.2518 & -0.0284 & 0.0049 & $* * *$ \\
Share of exp. on consumption & 0.7243 & 0.6871 & 0.0372 & 0.0052 & \\
Total consumption & & & & & \\
Budget share for food & 0.6155 & 0.6176 & -0.0020 & 0.0044 & NS \\
Budget share for housing & 0.1438 & 0.1373 & 0.0065 & 0.0027 & $*$ \\
Budget share for education & 0.0670 & 0.1092 & 0.0063 & 0.0034 & $*$ \\
Budget share for medical care & 0.0581 & 0.0806 & -0.0136 & 0.0029 & NS \\
\hline \hline
\end{tabular}

Note: Gaussian Kernel matching estimator (bandwith: 0.06). A common support is imposed by dropping 5 percent of the treatment observations at which the score density of the control observations is the lowest. ***: significant at 1\%;*: significant at 5\%; *: significant at 10\%. Source: RUMiC Rural Household Survey 2007. 
Table 8: Average treatment effects - Sub-samples

\begin{tabular}{|c|c|c|c|c|c|c|}
\hline & \multicolumn{3}{|c|}{ (1) Migrants sub-group } & \multicolumn{3}{|c|}{ (2) Migrants versus non-migrants } \\
\hline & Difference & Standard error & & Difference & Standard error & \\
\hline Per capita expenditure & 690 & 340 & $* *$ & 2407 & 297 & $* * *$ \\
\hline Per capita consumption & 985 & 233 & $* * *$ & 2286 & 152 & $* * *$ \\
\hline Total expenditure & & & & & & \\
\hline Share of exp. on family business & -0.0341 & 0.0090 & $* * *$ & -0.0226 & 0.0068 & *** \\
\hline Share of exp. on consumption & 0.0371 & 0.0093 & $* * *$ & 0.0347 & 0.0071 & $* * *$ \\
\hline Total consumption & & & & & & \\
\hline Budget share for food & -0.0140 & 0.0080 & $*$ & 0.0044 & 0.0060 & NS \\
\hline Budget share for durable goods & 0.0030 & 0.0050 & NS & 0.0057 & 0.0036 & NS \\
\hline Budget share for housing & 0.0169 & 0.0065 & $* * *$ & 0.0054 & 0.0045 & NS \\
\hline Budget share for education & -0.0099 & 0.0054 & * & -0.0211 & 0.0039 & $* * *$ \\
\hline Budget share for medical care & 0.0041 & 0.0045 & NS & 0.0056 & 0.0032 & * \\
\hline
\end{tabular}

Note: See Table 7. Column (1) refers to the sub-sample of migrant-sending households, and compares remittance-receiving with non-remittance-receiving households. Column (2) compares migrant-sending remittance-receiving households with non-migrant-sending non-remittance-receiving households. Source: RUMiC Rural Household Survey 2007. 
Table 9: Average treatment effects - Testing for heterogeneous effects by income quartile of the left behinds

\begin{tabular}{|c|c|c|c|c|c|c|c|c|c|c|c|c|}
\hline & \multicolumn{3}{|c|}{ 1st quartile } & \multicolumn{3}{|c|}{ 2nd quartile } & \multicolumn{3}{|c|}{ 3rd quartile } & \multicolumn{3}{|l|}{ 4th quartile } \\
\hline & Difference & Std err & & Difference & Std err & & Difference & Std err & & Difference & Std err & \\
\hline Per capita expenditure & 1053 & 734 & NS & 1897 & 251 & $* * *$ & 2121 & 257 & $* * *$ & 2433 & 609 & $* * *$ \\
\hline Per capita consumption & 1694 & 222 & $* * *$ & 1662 & 168 & $* * *$ & 1724 & 175 & $* * *$ & 2205 & 406 & $* * *$ \\
\hline Total expenditure & & & & & & & & & & & & \\
\hline Share of exp. on family business & -0.0443 & 0.0125 & $* * *$ & -0.0196 & 0.0090 & * & -0.0077 & 0.0092 & NS & 0.0196 & 0.0128 & NS \\
\hline Share of exp. on consumption & 0.0468 & 0.0128 & $* * *$ & 0.0205 & 0.0093 & $* *$ & 0.0115 & 0.0097 & NS & -0.0051 & 0.0132 & NS \\
\hline Total consumption & & & & & & & & & & & & \\
\hline Budget share for food & -0.0147 & 0.0111 & NS & -0.0205 & 0.0087 & $* *$ & -0.0249 & 0.0085 & $* * *$ & -0.0028 & 0.0103 & NS \\
\hline Budget share for durable goods & 0.0194 & 0.0064 & $* * *$ & 0.0173 & 0.0054 & $* * *$ & 0.0189 & 0.0053 & $* * *$ & -0.0020 & 0.0064 & NS \\
\hline Budget share for housing & 0.0006 & 0.0081 & NS & 0.0051 & 0.0065 & NS & 0.0175 & 0.0068 & ** & 0.0175 & 0.0092 & * \\
\hline Budget share for education & 0.0028 & 0.0064 & NS & -0.0042 & 0.0048 & NS & -0.0160 & 0.0055 & $* * *$ & -0.0216 & 0.0074 & $* * *$ \\
\hline Budget share for medical care & -0.0081 & 0.0067 & NS & 0.0022 & 0.0050 & NS & 0.0045 & 0.0047 & NS & 0.0089 & 0.0050 & NS \\
\hline
\end{tabular}

Note: See Table 7. Source: RUMiC Rural Household Survey 2007. 
Table 10: Average treatment effects - Testing for heterogeneous effects by location of the left behinds

\begin{tabular}{|c|c|c|c|c|c|c|}
\hline & \multicolumn{3}{|c|}{ Coast } & \multicolumn{3}{|c|}{ Inland } \\
\hline & Difference & Std err & & Difference & Std err & \\
\hline Per capita expenditure & 1632 & 405 & $* * *$ & 897 & 172 & $* * *$ \\
\hline Per capita consumption & 2312 & 235 & $* * *$ & 977 & 103 & $* * *$ \\
\hline Total expenditure & & & & & & \\
\hline Share of exp. on family business & -0.0317 & 0.0077 & $* * *$ & -0.0308 & 0.0058 & $* * *$ \\
\hline Share of exp. on consumption & 0.0486 & 0.0084 & $* * *$ & 0.0354 & 0.0060 & $* * *$ \\
\hline Total consumption & & & & & & \\
\hline Budget share for food & -0.0057 & 0.0070 & NS & 0.0015 & 0.0056 & NS \\
\hline Budget share for durable goods & 0.0103 & 0.0042 & $* *$ & 0.0054 & 0.0035 & NS \\
\hline Budget share for housing & 0.0053 & 0.0057 & NS & 0.0050 & 0.0043 & NS \\
\hline Budget share for education & -0.0141 & 0.0049 & $* * *$ & -0.0142 & 0.0034 & $* * *$ \\
\hline Budget share for medical care & 0.0043 & 0.0037 & NS & 0.0023 & 0.0031 & NS \\
\hline
\end{tabular}

Note: See Table 7. The regional classification is the following: Coast includes Hebei, Jiangsu, Zhejiang and Guangdong provinces; Inland includes Chongqing municipality and Sichuan, Henan, Hubei and Anhui provinces. Source: RUMiC Rural Household Survey 2007. 
Figure 1: Distribution of propensity scores of treatment and control groups, before and after matching

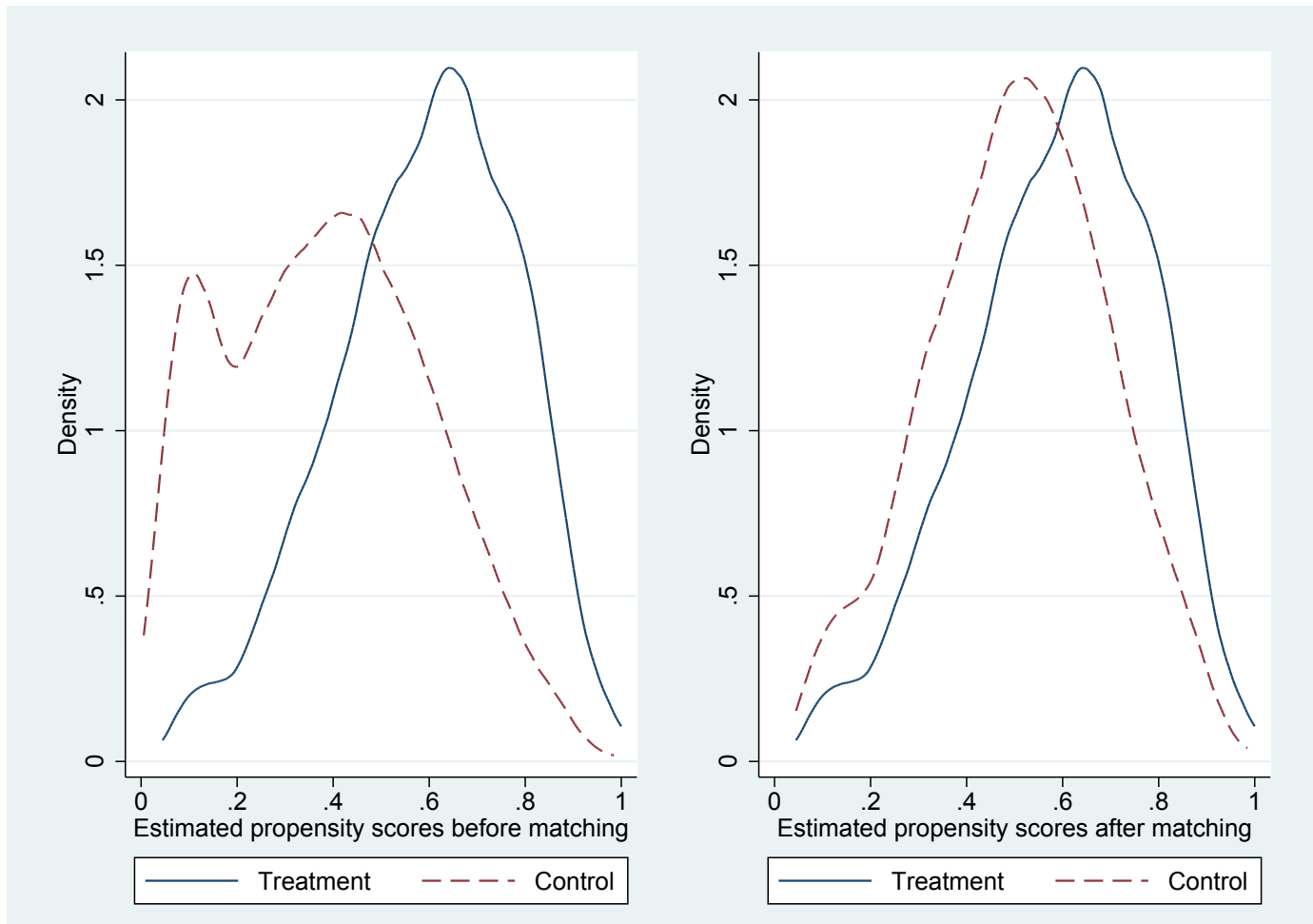

Source: RUMiC Rural Household Survey 2007. 